\title{
PAJANAN ASAP DALAM RUMAH TERHADAP KEJADIAN ISPA NONPNEUMONIA PADA ANAK BALITA DI KABUPATEN KAPUAS
}

\author{
Mayae Hugo $^{1}$, Ova Emilia², Mei Neni Sitaresmi ${ }^{3}$
}

\begin{abstract}
Background: Acute respiratory infections (ARI) is one of the main causes of disease burden in developing countries, and $40-60 \%$ patients visits at the health center. Riskesdes analysis report the under-five children who suffer from upper respiratory tract infection prevalence $42.8 \%$. ARI occurrence is affected by many factors, including environmental factors. Little attention has been given to indoor air pollution particularly for people in rural areas, although the known particles of smoke in the room known as the most influential factors on the health of children where children spend most of their time indoors

Objective: To know whether smoke exposure inside the house is a risk factor toward non pneumonia ARI among under-five children.

Method: This was a study using a case control study design. Subjects were under-five children aged 12-59 months old in Kapuas District taken by non probability sampling method. Sample size was 106, divided into two groups namely case $(n=53)$ and control $(n=53)$. Data analysis used univariate analysis, bivariate analysis, and multivariate analysis with logistic regression.

Result: Non pneumonia ARI had a 2.7 time greater risk of contracting under-five children exposed by smoke inside their house $(95 \% \mathrm{Cl}=1.16-6.60)$. Multivariate analysis proportion of house condition which was not really hygienic, member of family who contracted ARI, bad nutritional status had a significant relationship to non pneumonia ARI among under-five children.

Conclusion: Non pneumonia ARI among under-five children had a significant relationship to smoke exposure inside the house.
\end{abstract}

Keywords: non pneumonia ARI, smoke exposure inside the house, under-five children

\begin{abstract}
ABSTRAK
Latar Belakang: Infeksi saluran pernapasan akut (ISPA) merupakan salah satu penyebab utama beban penyakit di negara berkembang. Terdapat 40-60\% kunjungan pasien di pusat layanan kesehatan. Analisis Riskesdes melaporkan prevalensi anak-anak balita yang menderita infeksi saluran pernapasan atas $42,8 \%$. Kejadian ISPA dipengaruhi oleh banyak faktor, termasuk faktor lingkungan. Sedikitnya perhatian yang diberikan terhadap polusi udara dalam ruangan terutama bagi masyarakat di daerah pedesaan, meskipun partikel yang berasal dari asap di dalam ruangan dikenal sebagai faktor yang paling berpengaruh pada kesehatan anak di mana anak-anak menghabiskan sebagian besar waktu mereka di dalam ruangan.

Tujuan: Untuk mengetahui apakah paparan asap di dalam rumah merupakan faktor risiko terhadap non pneumonia ISPA pada balita.

Metode: Penelitian ini merupakan penelitian dengan menggunakan disain penelitian kasus kontrol. Subyek penelitian adalah balita berusia 12-59 bulan di Kabupaten Kapuas diambil dengan metode non probability sampling. Jumlah sampel adalah 106, dibagi menjadi dua kelompok yaitu kelompok kasus ( $\mathrm{n}=53$ ) dan kelompok kontrol $(n=53)$. Analisis data yang digunakan analisis univariat, analisis bivariat, dan analisis multivariat dengan regresi logistik.
\end{abstract}

1. Magister Kesehatan Ibu dan Anak-KR, Pascasarjana, Fakultas Kedokteran, Universitas Gadjah Mada Yogyakarta

2. Bagian Obstetri Ginekologi, Fakultas Kedokteran, Universitas Gadjah Mada Yogyakarta

3. Bagian Ilmu Kesehatan Anak, Fakultas Kedokteran, Universitas Gadjah Mada Yogyakarta 
Hasil dan Pembahasan: ISPA non pneumonia memiliki risiko 2,7 kali lebih besar menjangkiti anak yang terpapar asap di dalam rumah mereka $(95 \% \mathrm{Cl}=1,16-6,60)$. Proporsi analisis multivariabel kondisi rumah yang tidak benarbenar higienis, anggota keluarga yang terjangkit ISPA, status gizi buruk memiliki hubungan yang signifikan terhadap ISPA non pneumonia pada balita.

Kesimpulan: ISPA non pneumonia pada balita memiliki hubungan yang signifikan terhadap paparan asap di dalam rumah.

Kata kunci: ISPA non pneumonia, paparan asap di dalam rumah, balita

\section{PENDAHULUAN}

Penyakit infeksi saluran pernafasan akut (ISPA) merupakan salah satu masalah kesehatan yang utama di Indonesia karena masih tingginya angka kejadian ISPA terutama pada anak balita. ISPA merupakan salah satu penyebab utama kunjungan pasien di sarana kesehatan. Sebanyak 40-60\% kunjungan berobat di puskesmas dan 15-30\% kunjungan berobat di bagian rawat jalan dan rawat inap rumah sakit disebabkan oleh ISPA ${ }^{1}$

Meskipun pemberantasan penyakit ISPA telah dikembangkan sejak tahun 1984, bersamaan dengan dilancarkannya pemberantasan penyakit ISPA di tingkat global oleh organisasi kesehatan dunia, sampai saat ini penyakit ISPA merupakan penyakit yang sering terjadi pada anak dan masih menjadi masalah kesehatan masyarakat. Hal ini disebabkan angka kesakitan yang masih cukup tinggi dan dapat meningkat menjadi pneumonia. Sepuluh penyakit utama yang terkait dengan lingkungan dan menyebabkan pasien harus menjalani rawat jalan, dimana ISPA menduduki peringkat teratas dengan prevalensi 8,5\%. Berdasarkan hasil survey kesehatan rumah tangga tahun 2001 angka prevalensi ISPA sebesar $2 \%$ dari lima penyakit yang disurvei dengan prevalensi tinggi pada golongan bayi $39 \%$ dan balita $42 \% .^{2}$

Terjadinya ISPA dipengaruhi oleh banyak faktor diantaranya faktor lingkungan. Kondisi lingkungan yang berperan ialah polusi udara, termasuk asap rokok dan asap dapur. Selain polusi udara penyakit ISPA juga dipengaruhi oleh keadaan gizi, umur dan penyakit penyertanya. Risiko utamanya tergantung kemampuan anak atau ibu mereka untuk bertahan dari infeksi. Pajanan polusi udara dalam ruangan juga berperan penting, karena anak-anak menghabiskan sebagian besar waktunya di rumah. ${ }^{3}$

Analisis data Riskesdas 2007 dari jumlah balita 88.578 yang dianalisa didapatkan presentase balita yang menderita ISPA di Indonesia sebesar $42,8 \%$, bahwa pencemaran udara dalam rumah mempunyai hubungan yang bermakna dengan kejadian ISPA pada balita karenafaktor-faktor: bahan bakar memasak, perokok dalam rumah dan jenis lantai rumah. ${ }^{4} \mathrm{Di}$ negara berkembang ISPA termasuk sebagai penyebab utama dari beban penyakit yang berhubungan dengan paparan polutan dari bahan bakar biomassa lokal. ${ }^{5}$

Kejadian ISPA pada balita masih menjadi masalah di Indonesia dan salah satu faktor risiko pajanan pencemaran udara dalam rumah dapat berpengaruh terhadap kesehatan. Penelitian ini menjadi sangat penting karena dapat memberikan gambaran secara deskriptif bagaimana masyarakat atau orangtua sebagai orang yang menjaga kesehatan lingkungan terutama terhadap balita yang rentan terhadap pajanan asap didalam ruangan. Hal ini karena anakanak menghabiskan sebagian besar waktunya dirumah. ${ }^{6}$ Tujuan dari penelitian ini adalah mengidentifikasi hubungan pajanan asap dalam rumah terhadap kejadian ISPA non pneumonia pada balita serta faktor lain (kondisi rumah, anggota keluarga yang menderita ISPA, status gizi) berkontribusi terhadap resiko pajanan asap dalam rumah terhadap kejadian ISPA non pneumonia di Kabupaten Kapuas. 


\section{METODE PENELITIAN}

Jenis Penelitian ini adalah epidemiologis analitik observasional dengan rancangan kasus-kontrol (casecontrol study) menggunakan pendekatan kuantitatif dan kualitatif. Penelitian ini mengkaji hubungan antara kejadian ISPA non Pneumonia pada balita dengan pajanan asap dalam rumah. Populasi dalam penelitian ini adalah balita usia 12-59 bulan dengan sampel untuk kelompok kasus sebanyak 53 orang dan kontrol 53 orang sehingga total sampel 106 orang.Cara pengambilan sampel dengan cara non probability sampling yang memenuhi kriteria inklusi dan eksklusi. Kriteria inklusi adalah balita usia 12-59 bulan, tinggal bersama orangtua, dan bersedia menjadi responden. Sedangkan kriteria eksklusi meliputi: BBLR dan mempunyai penyakit kronis lainnya (TB Paru, riwayat asma).

Variabel dalam penelitian ini meliputi: variabel bebas yaitu pajanan asap dalam rumah, variabel terikat adalah kejadian ISPA non pneumonia pada anak balita, dan variabel luar adalah kondisi rumah, keberadaan anggota keluarga yang menderita ISPA nonpneumonia, dan status gizi. Analisis data yang digunakan adalah analisis univariat menggunakan distribusi frekuensi, analisis bivariat menggunakan uji chi-square $\left(x^{2}\right)$ pada tingkat kemaknaan $p<0,05$. Untuk menghitung adanya kekuatan hubungan dengan menggunakan OR, analisis multivariabel menggunakan regresi logistik dengan $\mathrm{Cl}(95 \%)$, dan sebagai data pendukung dilengkapi dengan wawancara mendalam.

\section{HASIL DAN PEMBAHASAN}

\section{Analisis Univariat}

Karakteristik responden sebanyak 106 orang sesuai dengan penghitungan besar sampel yang terdiri dari 53 kasus dan 53 kontrol, yang disajikan dalam tabel 1.

Tabel 1 Distribusi frekuensi subjek penelitian

\begin{tabular}{|c|c|c|c|}
\hline \multirow{2}{*}{ Variabel } & Kasus & Kontrol & total \\
\hline & $n(=53) \%$ & $n(=53) \%$ & $n(=106) \%$ \\
\hline \multicolumn{4}{|l|}{ Kelompok umur } \\
\hline 12-23 bulan & $15 \quad(28,3)$ & $16 \quad(30,2)$ & $31 \quad(29,3)$ \\
\hline 24-35 bulan & $17 \quad(32,1)$ & $11 \quad(20,8)$ & $28 \quad(26,4)$ \\
\hline $36-47$ bulan & $11(20,8)$ & $17 \quad(32,1)$ & $28 \quad(26,4)$ \\
\hline $48-60$ bulan & $10 \quad(18,9)$ & $9 \quad(17,0)$ & $19(17,9)$ \\
\hline \multicolumn{4}{|l|}{ Jenis kelamin } \\
\hline Laki-laki & $30 \quad(56,6)$ & $30 \quad(56,6)$ & $60 \quad(56,6)$ \\
\hline Perempuan & $23 \quad(43,4)$ & $23 \quad(43,4)$ & $46(43,4)$ \\
\hline
\end{tabular}

Tabel 1 menunjukkan bahwa kelompok umur 24-35 bulan memiliki prosentasi yang lebih besar untuk menderita ISPA non pneumonia dibandingkan dengan kelompok kontrol. Sedangkan berdasarkan jenis kelamin, balita laki-laki lebih banyak menderita ISPA non pneumonia ( $56,6 \%$ ) dibandingkan dengan balita perempuan ( $43,4 \%)$. 


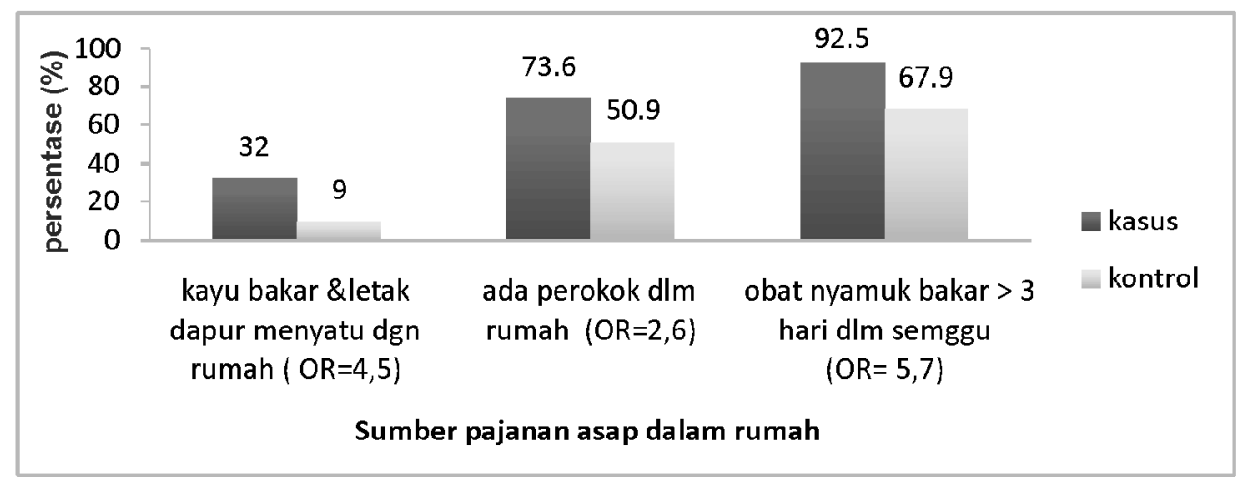

Gambar 1. Sumber pajanan asap dalam rumah

Gambar 2 menunjukkan sumber pajanan asap dalam rumah yang berasal dari perilaku merokok dan pemakaian obat nyamuk menunjukkan angka yang cukup tinggi yaitu pada kelompok kasus 92,5\% dan adanya perokok $73,6 \%$, begitupula dengan penggunaan kayu bakar sebesar 32\% lebih tinggi dibandingkan dengan kelompok kontrol yang $9 \%$.

Mendukung hasil analisis kuantitatif, dilakukan wawancara mendalam terhadap 3 orang responden. Berdasarkan hasil wawancara mendalam kebiasaan ibu dalam menggunakan kayu bakar sebagai bahan bakar memasak sehari-hari, dikarenakan kebiasaan dan kepraktisan dalam mencari bahan bakunya di tambah dengan mahalnya harga bahan bakar minyak tanah sehingga sulit terjangkau. Sikap ibu terhadap orang yang merokok, walaupun mereka tahu jika asap rokok tidak baik bagi kesehatan terutama terhadap anak-anak, namun dikarenakan pengertian dan pemahaman dari suami sendiri masih kurang terutama dengan perilaku merokok didalam rumah. Kebiasaan keluarga dalam menggunakan obat nyamuk bakar dirumah, kondisi keadaan lingkungan yang banyak nyamuk, kemudahan dalam mendapatkan obat nyamuk bakar dengan harga yang terjangkau dan dianggap efektif untuk mengusir nyamuk. Sehingga menjadi suatu kebiasaan untuk selalu menggunakan obat nyamuk sebagai obat pengusir nyamuk agar tidak masuk rumah dan menggigit.

Tabel 2. Distribusi frekuensi subjek penelitian

\begin{tabular}{lllll}
\hline \multicolumn{1}{c}{ Variabel } & \multicolumn{2}{c}{ Kasus } & \multicolumn{2}{c}{ Kontrol } \\
\cline { 2 - 6 } & $\mathrm{n}=53$ & $(\%)$ & $\mathrm{n}=53 \quad(\%)$ \\
\hline $\begin{array}{l}\text { Pajanan asap dalam rumah } \\
\quad \text { Terpapar }\end{array}$ & 36 & $(67,9)$ & 23 & $(43,4)$ \\
$\quad \begin{array}{l}\text { Tidak terpapar } \\
\text { Kondisi rumah } \\
\quad \text { Kurang }\end{array}$ & 17 & $(32,1)$ & 30 & $(56,6)$ \\
$\quad$ Baik & 34 & $(64,2)$ & 22 & $(41,5)$ \\
$\quad \begin{array}{l}\text { Keluarga yang menderita ISPA } \\
\quad \text { Ada }\end{array}$ & 19 & $(35,9)$ & 31 & $(58,5)$ \\
$\quad$ Tidak ada & 31 & $(58,5)$ & 19 & $(35,9)$ \\
$\begin{array}{l}\text { Status Gizi } \\
\quad \text { Kurang }\end{array}$ & 22 & $(41,5)$ & 34 & $(64,2)$ \\
$\quad$ Baik & 33 & $(62,3)$ & 21 & $(39,6)$ \\
\hline & 20 & $(37,7)$ & 32 & $(60,4)$ \\
\hline
\end{tabular}


Pada Tabel 2 terlihat bahwa pajanan asap dalam rumah pada kelompok kasus $(67,9 \%)$ lebih tinggi dibandingkan kelompok kontrol (43,4\%). Kondisi rumah yang kurang baik lebih banyak ditemukan pada kelompok kasus (64,15\%) dibandingkan kontrol (41,5\%). Sedangkan keluarga yang menderita ISPA lebih banyak ditemukan pada kelompok kasus $(58,5 \%)$ dibandingkan kelompok kontrol (35,9\%). Balita yang menderita status gizi kurang pada kelompok kasus sebesar $62,3 \%$ dan pada kelompok kontrol hanya $39,6 \%$.

\section{Analisis Bivariat}

Tabel 3. Analisis Chi-square variabel pajanan asap dalam rumah terhadap kejadian ISPA non pneumonia)

\begin{tabular}{|c|c|c|c|c|c|}
\hline \multirow[b]{2}{*}{ Variabel } & \multicolumn{2}{|c|}{ ISPA nonpneumonia } & \multirow[b]{2}{*}{$x^{2}$} & \multirow{2}{*}{$\begin{array}{c}\text { OR } \\
(95 \% \mathrm{Cl})\end{array}$} & \multirow[b]{2}{*}{$p$} \\
\hline & $\begin{array}{c}\text { Kasus } \\
n=(53) \%\end{array}$ & $\begin{array}{c}\text { Kontrol } \\
n=(53) \%\end{array}$ & & & \\
\hline \multicolumn{6}{|l|}{ Pajanan asap } \\
\hline Terpapar & $36(67,9)$ & $23(43,4)$ & 6,46 & 2,7 & $* 0,01$ \\
\hline Tidakterpapar & $17(32,1)$ & $30(56,6)$ & & $(1,16-6,60)$ & \\
\hline
\end{tabular}

Keterangan * : signifikan

Hasil uji chi-quare pada Tabel 3. menunjukkan hubungan yang bermakna ditunjukan dengan nilai $p=0.01$ antara pajanan asap dalam rumah dengan kejadian ISPA non Pneumonia pada balita dengan nilai OR sebesar 2,7 (95\% $\mathrm{Cl}: 1,16-6,60)$. Adanya pajanan asap dalam rumah meningkatkan kejadian ISPA non pneumonia pada balita sebesar 2,7 kali.
Berdasarkan hasil wawancara disimpulkan bahwa pajanan asap dalam rumah yang bersumber dari kegiatan di dalam rumah karena: kondisi ekonomi keluarga, kurangnya pemahaman keluarga tentang bahaya asap terhadap anak, dan kebiasaan terhadap penggunaan obat nyamuk bakar yang efektif dalam mengusir nyamuk dalam mencegah anak terhadap gigitan nyamuk.

Tabel 4. Hubungan variabel luar kondisi rumah, keluarga yang menderita ISPA, status gizi terhadap kejadian ISPA non Pneumonia pada balita

\begin{tabular}{|c|c|c|c|c|c|}
\hline \multirow[b]{2}{*}{ Variabel } & \multicolumn{2}{|c|}{ ISPA non pneumonia } & \multirow[b]{2}{*}{$x^{2}$} & \multirow{2}{*}{$\begin{array}{c}\text { OR } \\
(95 \% \mathrm{Cl})\end{array}$} & \multirow[b]{2}{*}{$p$} \\
\hline & $\begin{array}{c}\text { Kasus } \\
n=53 \quad \%)\end{array}$ & $\begin{array}{l}\text { Kontrol } \\
n=53(\%)\end{array}$ & & & \\
\hline \multicolumn{6}{|l|}{ Kondisi rumah } \\
\hline Kurang & $34(64,2)$ & $22(41,5)$ & \multirow{2}{*}{5,45} & 2,5 & \multirow{2}{*}{$0,01^{*}$} \\
\hline baik & $19(35,9)$ & $31(58,5)$ & & $(1,07-5,95)$ & \\
\hline \multicolumn{6}{|l|}{ Keluarga yang } \\
\hline menderita ISPA & & & \multirow{3}{*}{5,45} & 2,5 & \multirow{3}{*}{$0,01^{*}$} \\
\hline ada & $31(58,5)$ & $19(35,9)$ & & $(1,07-5,95)$ & \\
\hline tidak ada & $22(41,5)$ & $34(64,2)$ & & & \\
\hline \multicolumn{6}{|l|}{ Status gizi } \\
\hline kurang & $33(62,3)$ & $21(39,6)$ & \multirow{2}{*}{5,44} & 2,5 & \multirow{2}{*}{$0,01^{*}$} \\
\hline baik & $20(37,74)$ & $32(60.38)$ & & $(1,07-5,92)$ & \\
\hline
\end{tabular}

Keterangan $^{*}:$ signifikan 
Tabel 4. menunjukkan bahwa kondisi rumah yang kurang pada kelompok balita dengan kejadian ISPA non pneumonia 2,5 kali lebih banyak ( $95 \% \mathrm{Cl}$; 1,07-5,95) dibandingkan pada kelompok balita yang tidak menderita ISPA nonpneumonia. Keberadaan anggota keluarga yang menderita ISPA berpeluang 2,5 kali lebih besar $(95 \% \mathrm{Cl} ; 1,07-5,95)$ untuk menyebabkan kejadian ISPA non pneumonia pada balita dibandingkan dengan balita yang tidak menderita ISPA non pneumonia. Berdasarkan status gizi diperoleh hasil bahwa status gizi yang kurang berpeluang 2,5 lebih besar ( $95 \% \mathrm{Cl} ; 1,07-5,92)$ untuk menyebabkan kejadian ISPA non pneumonia pada balita dibandingkan dengan kontrol.

\section{Analisis Multivariabel}

Analisis multivariabel dilakukan untuk melihat hubungan pajanan asap dalam rumah dengan kejadian ISPA non pneumonia pada balita, dengan menganalisa secara bersama-sama dengan memasukkan variabel luar yang bermakna pada analisis bivariat. Variabel luar yang bermakna adalah kondisi rumah, keberadaan anggota keluarga yang menderita ISPA, dan status gizi.

Tabel 5 Analisis regresi logistik

\begin{tabular}{|c|c|c|c|c|}
\hline \multirow{2}{*}{ Variabel } & Model 1 & Model 2 & Model 3 & Model 4 \\
\hline & OR & OR & OR & OR \\
\hline \multicolumn{5}{|c|}{ Pajanan asap dalam } \\
\hline rumah & 2,7 & 2,9 & 3,6 & $3,7^{*}$ \\
\hline Terpapar & $(1,25-6,10)$ & $(1,30-6,73)$ & $(1,50-8,67)$ & $(1,52-9,06)$ \\
\hline Tidak terpapar & 1 & 1 & 1 & 1 \\
\hline Kondisi rumah & & 2,7 & 2,5 & 2,2 \\
\hline Kurang & & $(1,19-6,15)$ & $(1,11-6,01)$ & $(0,95-5,38)$ \\
\hline Baik & & 1 & & 1 \\
\hline \multicolumn{5}{|l|}{ Anggota keluarga } \\
\hline menderita ISPA & & & 3 & $2,8^{*}$ \\
\hline Ada & & & $(1,27-7,21)$ & $(1,16-6,78)$ \\
\hline Tidak ada & & & 1 & 1 \\
\hline Status gizi & & & & 2 \\
\hline Kurang & & & & $(0,85-4,83)$ \\
\hline Baik & & & & 1 \\
\hline Deviance & 140,40 & 134,44 & 127,80 & 125,21 \\
\hline$R 2$ & 0,044 & 0,085 & 0,13 & 0,15 \\
\hline$n$ & 106 & 106 & 106 & 106 \\
\hline
\end{tabular}

Pada Tabel 5 model 1 hasil analisis regresi logistik menunjukkan OR sebesar 2,7 (95\% Cl:1,25-6,10). Hal ini berarti bahwa proporsi balita yang terkena pajanan asap dalam rumah memiliki resiko 2,7 kali lebih besar mengalami kejadian ISPA non pneumonia. Berdasarkan nilai $R^{2}=0,044$ menggambarkan pajanan asap dalam rumah dapat memprediksi kejadian ISPA non pneumonia sebesar $4 \%$. Terdapat $96 \%$ faktor lain yang menyebabkan kejadian ISPA non pneumonia tapi tidak diteliti.
Model 2 dibangun dengan tujuan untuk mengetahui hubungan variabel pajanan asap dalam rumah dengan kejadian ISPA non pneumonia pada balita dengan menyertakan variabel kondisi rumah. Hasil analisis menunjukkan terjadi peningkatan proporsi pajanan asap dalam rumah pada kelompok balita dengan kejadian ISPA non pneumonia 2,9 (95\% $\mathrm{Cl}: 1,30-6,73)$ kali dibandingkan balita yang tidak mengalami ISPA non pneumonia. Keberadaan variabel kondisi rumah dapat memprediksi kejadian 
ISPA non pneumonia meningkat dari $4 \%$ menjadi $8 \%$ tetapi kontribusi variabel kondisi rumah dalam memprediksi kejadian ISPA non pneumonia pada balita hanya sebesar $4 \%$.

Model 3 dibangun dengan tujuan untuk mengetahui hubungan variabel pajanan asap dalam rumah dengan kejadian ISPA non pneumonia pada balita dengan mengikutkan variabel kondisi rumah dan keberadaan anggota keluarga yang menderita ISPA. Hasil analisis menunjukkan peningkatan proporsi pajanan asap dalam rumah dengan kejadian ISPA non pneumonia pada balita 3,6 (95\% Cl: 1,50$8,67)$ kali lebih besar dibandingkan dengan kelompok balita yang tidak menderita ISPA non pneumonia dan ini bermakna secara praktis dan statistik. Hasil analisis model 3 variabel kondisi rumah menunjukkan hasil yang bermakna ( $\mathrm{OR}=2,5 ; 95 \% \mathrm{Cl}=1,11-6,01)$, sementara variabel keluarga yang menderita ISPA juga menunjukkan hubungan yang bermakna $(O R=3$; $95 \% \mathrm{Cl}=1,27-7,21)$. Model ini dapat memprediksi kejadian ISPA non pneumonia 13\% yang ditunjukan dengan nilai $R^{2}=0,013$ dan nilai OR pada model 3 ini bermakna secara praktis maupun statistik dalam memprediksi kejadian ISPA non pneumonia

Model 4 dibangun dengan tujuan untuk mengetahui hubungan variabel pajanan asap dalam rumah dengan menyertakan variabel luar secara bersamaan yaitu kondisi rumah, keberadaan anggota keluarga yang menderita ISPA, dan status gizi. Hasil analisis menunjukkan variabel kondisi rumah, status gizi tidak bermakna secara statistik karena nilai confidence interval melewati angka 1 , sedangkan yang mempunyai hubungan bermakna secara praktis dan statistik variabel keberadaan anggota keluarga yang menderita ISPA (OR=2,8; 95\% $\mathrm{Cl}=1,16-6,78)$, sedangkan terhadap hubungan pajanan asap dalam rumah dengan kejadian ISPA non pneumonia menunjukkan hasil yang bermakna dengan meningkatnya $\mathrm{OR}=3,7(95 \% \mathrm{Cl}=1,52-9,06)$. Model ini dapat memprediksi kejadian ISPA non pneumonia $15 \%$.
Berdasarkan hasil analisis permodelan diatas, model 3 dipilih karena secara statistik dan praktis lebih efektif dan efisien dalam menggambarkan hubungan pajanan asap dalam rumah dengan kejadian ISPA non pneumonia. Hubungan pajanan asap dalam rumah dengan kejadian ISPA non pneumonia menunjukkan (OR=3,6:95\% $\mathrm{Cl}=1,50$ $8,67)$. Artinya balita yang terkena pajanan asap dalam rumah beresiko 3,6 kali lebih besar untuk menderita ISPA non pneumonia dibandingkan dengan yang tidak terpajan asap dalam rumah setelah dikontrol dengan variabel kondisi rumah dan keberadaan anggota keluarga yang menderita ISPA. Model 3 dipilih karena memiliki nilai $\mathrm{R}^{2}$ yang lebih tinggi, nilai devian yang lebih rendah dan rentang kepercayaan yang lebih sempit serta variabel yang dimasukan bermakna secara statistik dan praktis.

Hasil analisis bivariat pada penelitian ini membuktikan bahwa pajanan asap dalam rumah mempunyai hubungan yang bermakna dengan kejadian ISPA nonpneumonia. Hasil analisis bivariat hubungan antara kondisi rumah,anggota keluarga yang menderita ISPA, status gizi dengan kejadian ISPA non pneumonia mempunyai hubungan yang bermakna.

Berdasarkan hubungan pajanan asap dalam rumah dengan kejadian ISPA non pneumonia menunjukkan hubungan yang bermakna. Hasil ini sejalan dengan penelitian tentang balita yang terpajan oleh pencemaran dari hasil pemakaian kayu bakar untuk memasak. Kebiasaan membawa balita kedapur dapat menyebabkan balita terkena resiko 2,3 kali lebih besar mengalami penyakit ISPA dibandingkan balita yang tidak selalu dibawa kedapur menerima resiko 1,5 kali dibandingkan dengan yang tidak terkena pajanan asap dari kegiatan memasak didapur. ${ }^{5}$ Polusi udara dalam ruangan yang disebabkan paparan asap dari kegiatan memasak dengan pemakaian bahan bakar biomassa (kayu, kotoran hewan, jerami) mempunyai hubungan yang signifikan dengan preva-lensi ISPA pada balita di Zimbabwe. ${ }^{6}$ 
Pencemaran udara didalam ruangan selain berasal dari penetrasi polutan dari luar ruangan dapat pula berasal dari sumber polutan didalam ruangan, seperti asap rokok, asap yang berasal dari dari dapur atau pemakaian obat nyamuk bakar. Bahan partikel yang terdapat dalam ruangan dapat saja sama dengan yang diluar ruangan, hanya saja kadarnya yang berbeda, partikel dalam ruangan dapat terdiri dari partikel debu, partikel asap rokok, aero allergen dan bahan kecantikan. ${ }^{7}$

Berdasarkan status pajanan asap dalam rumah diperoleh hasil bahwa sebagian besar kejadian ISPA nonpneumonia didapatkan pada balita yang terpajan asap dalam rumah. Berdasarkan sumber pajanan yaitu adanya perilaku merokok didalam rumah, penggunaan kayu bakar dalam aktifitas memasak, kebiasaan pengunaan obat nyamuk bakar setiap hari, dari hasil wawancara mendalam diketahui bahwa faktor ketidaktahuan terhadap bahaya pencemaran udara dan kurangnya kesadaran dari anggota keluarga yang merokok untuk tidak merokok dalam rumah, dan kebiasaan menggunakan obat nyamuk bakar untuk menghindari gigitan nyamuk. Faktor polusi udara lingkungan bagi penderita ISPA disebabkan oleh jumlah orang yang merokok dirumah, dan jumlah rokok yang dihisap, serta masuknya asap dapur kedalam ruangan keluarga (karena ventilasi tidak baik) dan jarak rumah dari bengkel las/tempat sampah. ${ }^{8}$

Terdapat lima kategori faktor yang mempengaruhi kesakitan dan kematian anak di negara berkembang dimana faktor kedua menjelaskan peran lingkungan yang terkontaminasi yang meliputi udara, makanan, tanah, benda mati, kulit, jari, serangga, vektor sebagai salah satu faktor penyebab yang mempengaruhi dari kelangsungan hidup anak. Setiap efek (penyakit) tidak pernah tergantung pada salah satu faktor tetapi pada sejumlah faktor penyebab dalam rangkaian kausalitas sebelumnya.

Hasil analisis kepadatan dan ventilasi mempunyai hubungan yang signifikan terhadap kejadian ISPA non pneumonia pada balita, berdasarkan karakteristik responden dengan kondisi rumah yang kurang mempunyai resiko 2,5 kali terhadap kejadian ISPA non pneumonia. Penelitian yang dilakukan di Kecamatan Rungkut dimana penyakit ISPA memiliki urutan yang pertama, menyatakan bahwa kepadatan dan ventilasi yang kurang mempunyai hubungan yang bermakna dengan kejadian ISPA. ${ }^{9}$ Kepadatan penghuni merupakan faktor resiko kejadian ISPA karena jumlah penghuni rumah sangat berpengaruh terhadap jumlah koloni kuman penyebab penyakit menular. Kondisi ventilasi yang tidak baik berpengaruh terhadap sirkulasi udara,sehingga udara yang kotor tidak bisa keluar, debu menumpuk dan menjadi lembab menyebabkan jamur, tungau mudah berkembang biak sehingga dapat berpengaruh terhadap kesehatan penghuni rumah. ${ }^{10}$

Berdasarkan analisis terhadap variabel anggota keluarga yang menderita ISPA diperoleh hasil bahwa resiko kejadian ISPA non pneumonia pada balita menunjukkan hubungan yang bermakna, dimana proporsi anggota keluarga yang menderita ISPA berpeluang 2,5 kali lebih besar pada balita dengan kejadian ISPA non pneumonia dibandingkan dengan balita yang tidak menderita ISPA non pneumonia. Kontak antara balita dengan orang dewasa atau balita penderita ISPA mempunyai hubungan bermakna, dimana balita yang terpapar kontak dengan balita dan orang dewasa yang sakit ISPA beresiko 1,9 kali untuk terkena ISPA terutama yang tinggal dalam satu rumah. ${ }^{11}$ Penggunaan masker dalam pengawasan penyebaran virus pernafasan di rumah tangga oleh orang dewasa terhadap anak yang menderita infeksi saluran pernafasan, pemakaian masker mempunyai hubungan yang bermakna dalam menurunkan resiko penularan berhubungan dengan Infeksi pernafasan. ${ }^{12}$

Berdasarkan analisis variabel status gizi diperoleh hasil bahwa terdapat hubungan yang signifikan antara status gizi dengan kejadian ISPA non pneumonia, tetapi setelah dianalisis multivariat dengan beberapa variabel lain status gizi mempunyai 
hubungan yang lemah karena tidak bermakna secara statistik. Nutrisi dan status gizi merupakan hal yang penting terhadap terjadinya suatu infeksi, gizi yang cukup melindungi tubuh dari infeksi karena sistem imunitas akan berfungsi dengan baik. ${ }^{13}$ Kurangnya gizi menyebabkan penurunan imunitas sehingga menyebabkan mudah terjadi infeksi. Kejadian ISPA pada balita sebanyak 132 (75\%) adalah balita yang menderita kurang gizi tingkat I sampai tingkat IV, dan sisanya 44 (25\%) balita dengan gizi baik. ${ }^{14}$ Kejadian ISPApada balita sama pada balita dengan gizi kurang maupun normal tehadap infeksi saluran pernafasan bagian atas, kecuali pada balita dengan gizi kronis yang dapat menyebabkan komplikasi dari ISPA yaitu pneumonia. ${ }^{15}$

Gizi merupakan faktor yang dapat meningkatkan daya tahan tubuh dari serangan penyakit. Keadaan gizi merupakan refleksi persediaan gizi dalam tubuh. Tingkat pertumbuhan fisik dan imunologik seseorang dipengaruhi oleh adanya persediaan gizi dalam tubuh dan kekurangan zat gizi akan meningkatkan kerentanan dan beratnya infeksi suatu penyakit. ${ }^{16}$

\section{KESIMPULAN DAN SARAN}

Balita yang terpajan asap dalam rumah mempunyai resiko 2,7 kali lebih besar terhadap kejadian ISPA non pneumonia dibandingkan dengan balita yang tidak dengan kejadian ISPA non pneumonia. Kejadian ISPA non pneumonia pada Balita mempunyai hubungan yang bermakna dengan pajanan asap dalam rumah pemakaian obat nyamuk sebanyak $92 \%$, adanya perokok sebesar $72 \%$ dan penggunaan kayu bakar untuk memasak sebanyak 32\%. Kondisi rumah yang kurang baik, adanya anggota keluarga yang menderita ISPA, status gizi yang kurang mempunyai hubungan yang bermakna dengan kejadian ISPA non pneumonia pada balita.

Hasil wawancara mendalam pajanan asap dalam rumah yang bersumber dari perilaku; 1 ) penggunaan kayu bakar dikarenakan; kepraktisan dan kemudahan dalam mencari bahan kayu bakar dan mahalnya harga minyak tanah;2) perilaku merokok dikarenakan kurangnya pemahaman keluarga tentang bahaya asap terhadap anak, walaupun tahu kalau efek dari asap rokok tidak baik untuk kesehatan, tetapi mereka tidak tahu jika merokok didalam rumah juga berpengaruh terhadap kesehatan anak; 4) kebiasaan terhadap penggunaan obat nyamuk bakar dikarenakan efektif dalam mengusir nyamuk dan harganya yang terjangkau. 5) belum pernah diberikan penyuluhan tentang dampak pencemaran udara dalam rumah oleh petugas kesehatan.

Perlu meningkatkan pengetahuan orang tua terutama yang mempunyai anak-anak balita tentang bahaya pencemaran udara di dalam rumah terhadap kesehatan anak dengan menghindari/membatasi pemakaian obat nyamuk bakar, merokok didalam rumah dan menggunakan kayu bakar, Sehingga orang tua dapat menciptakan lingkungan yang bebas asap.Bagi petugas kesehatan perlu memberikan penyuluhan dalam upaya meningkatkan kesadaran orang dewasa untuk bisa menciptakan lingkungan yang sehat dan bebas polusi.

\section{DAFTAR PUSTAKA}

1. Depkes RI, Info penyakit menular, 2004 available from: http://www. Depkes.go.id/ [accessed 28 oktober 2009].

2. Depkes RI, Informasi tentang ISPA pada anak balita, Pusat penyuluhan kesehatan Masyarakat. Jakarta. 2003

3. Supraptini, Faktor-faktor pencemaran yang berhubungan dengan kejadian ISPA pada balita di Indonesia, JKPKBPPK.2009.[available from: http:/ /www. jkpkbppk.go.id/ [accessed 28 oktober 2009]

4. Ezzati, M. and Kemmen,D.M.,Quantifiying the effecth of exposure to indoor air pollition from Biomass combustion on acute respiratory infection in developing Countries.inviron health perspect. 2001;109:481-488

5. Sukar, L.A., Tri Tugaswati, A.A.A. \& Kasnodiharjo. Resiko relatif lingkungan sosial dan kimia terhadap kejadian penyakit ISPA-pneumonia di Indramayu, Jawa Barat. Cermin dunia kedokteran,1997;144:4144 
6. Mishra, V. Indoor air pollution from biomass combustion and acute respiratory illness in preschool age children in Zimbabwe. Int $\mathrm{J}$ Epidemiol,2003;32:847-853.

7. Mukono, Pencemaran Udara dan Pengaruhnya Terhadap Gangguan Pernafasan. Cetakan 3. Surabaya. Airlangga University Press.1997

8. Lubis,l. Pengaruh lingkungan terhadap penyakit infeksi saluran pernafasan akut (ISPA). Cermin dunia kedokteran.1991: 70.15-17

9. Yusup, N.A. \& Sulistyorini, I. Hubungan sanitasi rumah secara fisik dengan kejadian ISPA pada balita. Jurnal Kesehatan Lingkungan,1997 1(2):110-118.

10. Smith, K.R., Samet, J.M., Romieu, I., Bruce, N. Indoor air polution in developing countries and acute lower respiratory infections in children, Thorax, 2000; 55: 518-532.

11. Viboud, C., Boelle, P.Y., Cauchemez, S., Lavenu, A., valleron, A.J., Flahauth, A., Carrat, F., Risk factor of influenza trasmission in houselholds. British journal of General practice. 2004; 54, 684-689

12. Maclntyre, R.C., Cauchemez. S., Dwyer. D.E., Seale. H., Cheung. P., Browne. G., Fasher. M., Wood.J., Gao.
Z., Booy.R., and Ferguson. N., Face mask use and control of Respiratory Virus tranmission in household. Emg infect Diseases, 2009; vol 15;2.

13. Chatterjee, S.A study of epidemiological factors related to acute respiratory infection (ARI) in Under five children attending the immunization clinic of calcuta national medical college and Hospital. The int of pulm med. 2007;7 (2):1-8.

14. Fahmi, Z. \& White, F., A comparison of "cough and cold" and pneumonia; Risk factor for pneumoniain children under 5 years revisited. Int J infect Dis, 2002; 6,294-301.

15. Sloan,S., Gildea, A., Stewart, M., Sneddon, H. \& Waniec, D.,(2007). Early weaning is related to weigh and rate of weigh gain onfacy. Child care health Dev,34(1):59-64.

16. Muhe,L., (1994) Child health and acute respiratory infection in ethiopia, Umea University medical dessertasions. Sweden

17. WHO, Indikator Perbaikan Kesehatan Lingkungan Anak, Jakarta: ECG.2008 